\title{
Issues and Challenges in the Application of the IEUBK Model in the Health Risk Assessment of Lead: A Case Study from Blantyre Malawi
}

\author{
Wells Utembe ${ }^{1,2, *}$ and Mary Gulumian $1,3,4$ (D) \\ 1 Toxicology and Biochemistry Department, National Institute for Occupational Health and National Health \\ Laboratory Service, Johannesburg 2000, South Africa; maryg@nioh.ac.za \\ 2 School of Public Health, University of the Witwatersrand, Johannesburg 2000, South Africa \\ 3 Molecular Medicine and Haematology, University of the Witwatersrand, Johannesburg 2000, South Africa \\ 4 Water Research Group, Unit for Environmental Sciences Management, North West University, \\ Potchefstroom 2351, South Africa \\ * Correspondence: wellsu@nioh.ac.za
}

check for updates

Citation: Utembe, W.; Gulumian, M. Issues and Challenges in the Application of the IEUBK Model in the Health Risk Assessment of Lead: A Case Study from Blantyre Malawi. Int. J. Environ. Res. Public Health 2021, 18, 8207. https://doi.org/10.3390/ ijerph18158207

Academic Editors: Jose A. Centeno and Jacques Gardon

Received: 27 May 2021

Accepted: 7 July 2021

Published: 3 August 2021

Publisher's Note: MDPI stays neutral with regard to jurisdictional claims in published maps and institutional affiliations.

Copyright: (C) 2021 by the authors Licensee MDPI, Basel, Switzerland. This article is an open access article distributed under the terms and conditions of the Creative Commons Attribution (CC BY) license (https:/ / creativecommons.org/licenses/by/ $4.0 /)$.

\begin{abstract}
The risk assessment of lead $(\mathrm{Pb})$ requires the use of biokinetic models to translate measured concentrations of $\mathrm{Pb}$ in food and environmental media into blood lead ( $\mathrm{BPb})$. The aim of this study was to assess the applicability of the Integrated Exposure Uptake Biokinetic (IEUBK) model in the health risk assessment of $\mathrm{Pb}$ among children in Blantyre. Children (152) aged 1-6 years were recruited into this cross-sectional study, and foods, house dust, playground soil, water, and venous blood $(1 \mathrm{~mL})$ were collected and analyzed for $\mathrm{Pb}$. A seven-day food frequency questionnaire (FFQ) was used to collect food consumption data. The concentrations of $\mathrm{Pb}$ ranged from 0.01 to $3.3 \mathrm{mg} / \mathrm{kg}$ in food, 2.3 to $265 \mathrm{mg} / \mathrm{kg}$ and 1.5 to $482 \mathrm{mg} / \mathrm{kg}$ in house dust and playground soil, respectively, as well as $2.0 \mu \mathrm{g} / \mathrm{dL}$ to $50.4 \mu \mathrm{g} / \mathrm{dL}$ and 6.8 to $39.2 \mu \mathrm{g} / \mathrm{dL}$ for measured and predicted $\mathrm{BPb}$, respectively. Various statistical tests indicated less than satisfactory agreement between measured and predicted $\mathrm{BPb}$ values. Despite the lack of reliable food consumption data and other limitations, both the predicted and measured $\mathrm{BPb}$ values indicate that children in Blantyre are exposed to high levels of $\mathrm{Pb}$, largely through food and soil as a minor source.
\end{abstract}

Keywords: lead; exposure; biokinetic modelling; children

\section{Introduction}

Lead $(\mathrm{Pb})$ causes many adverse effects in adults and children, including anaemia [1], neurobehavioral [2] and nephrotoxic effects [3], and hypertension [4]. In children, $\mathrm{Pb}$ has especially been widely associated with reductions in intelligence quotience (IQ) and school performance, as well as an increase in violent behavior [5]. While some effects such as anaemia and nephrotoxic effects occur at high exposure levels, the effects on IQ, ability to pay attention, and academic achievement have been shown to occur even at low blood lead $(\mathrm{BPb})$ concentrations [6]. Compared to adults, children are particularly vulnerable to $\mathrm{Pb}$ exposure and poisoning because of their greater hand-to-mouth activity, greater absorptive capacity in the digestive tract, and rapid development of the nervous system [7]. Protection of children from exposure to $\mathrm{Pb}$ is very important for lifelong good health since the effects of $\mathrm{Pb}$ exposure cannot be reversed [6].

In Malawi, the regulation on the sale and use of leaded petrol that was promulgated in 2006 is expected to significantly reduce $\mathrm{Pb}$ exposure. However, a large body of evidence shows that other common sources and pathways of $\mathrm{Pb}$ including $\mathrm{Pb}$-based house paint [8], food [9], water [10], toys [11], lead-laced china ware [12], cosmetics [13], and medicines [14], could also be significant potential sources of exposure to $\mathrm{Pb}$ for children in Malawi. Therefore, there is a need to assess exposure to $\mathrm{Pb}$ from different sources and its associated risks among various populations in Malawi. 
Exposure to $\mathrm{Pb}$ may be assessed using bottom-up approaches, where chemicals are measured in environmental media such as air, water and food, or using top-down or biomonitoring approaches where chemicals are measured in bodily fluids or other specimens. The former approach furnishes information on external exposures and their sources, without providing information on internal doses, while the latter approach provides the actual concentrations of a chemical in specified bodily fluids, tissues, or specimens, albeit without providing information about sources of exposure [15]. Both approaches (i.e., measurement of $\mathrm{Pb}$ in environmental media as well as biomonitoring) are used in the exposure and risk assessment of $\mathrm{Pb}$.

In particular, the risk assessment of $\mathrm{Pb}$ in environmental media is used to provide information on the level of contamination of specific media (food, water, air, soil, etc.), which can in turn be converted to potential doses of $\mathrm{Pb}$. This approach requires the comparison of the amount of $\mathrm{Pb}$ intake from the environmental media with safe levels of $\mathrm{Pb}$ such as the reference dose (RfD), the acceptable daily intake (ADI), or the provisional tolerable weekly intake (PTWI). However, as the WHO withdrew the PTWI for Pb [16] and also since $\mathrm{Pb}$ does not have a reference dose [17], health risk assessment of $\mathrm{Pb}$ from various environmental media and food requires translation of the $\mathrm{Pb}$ intake from these sources into $\mathrm{BPb}$ using biokinetic models. The predicted $\mathrm{BPb}$ are subsequently correlated with potential health effects that have been observed at various $\mathrm{BPb}$ ranges [18].

Only a few biokinetic models have been developed for converting Pb levels in environmental media to $\mathrm{Pb}$ levels in human blood or tissues. These models include the United States Environmental Protection agency (USEPA) Integrated Exposure Uptake Biokinetic (IEUBK) model [19], the Carlisle and Wade model [20], the California Department of Toxic Substances Control LeadSpread model [21], the All-Ages Lead model (AALM) [22], and O'Flaherty physiologically based toxicokinetic (PBTK) model [23]. These biokinetic models are developed based on the mechanistic understanding of the processes occurring in the body, and are therefore quite challenging to develop in terms of human, technical, and financial resources. Hence, for developing countries such as Malawi, it is more prudent to assess the applicability of these existing biokinetic models before any attempts to develop local biokinetic models.

This study used the IEUBK model because it is validated, it is reported to be accurate [24-26], and because it was specifically designed to predict $\mathrm{BPb}$ concentrations in children between one and six years of age exposed to $\mathrm{Pb}$ in their environment. For these reasons, the IEUBK is the most widely used model for the health risk assessment of $\mathrm{Pb}$ in children. The model allows the user to input relevant absorption parameters (e.g., the fraction of $\mathrm{Pb}$ absorbed from food) as well as intake and exposure rates [27], and has been used in many countries for different applications. For example, the IEUBK model could be used to predict $\mathrm{BPb}$ values resulting from exposure to $\mathrm{Pb}$ from different sources [28-30], to estimate the contribution of a source of $\mathrm{Pb}$ (e.g., tap water) to $\mathrm{BPb}[28,29]$, to determine exposure routes [31], as well as to estimate the concentration of $\mathrm{Pb}$ in soil in remediation that would result in a predetermined percentage of children (such as 10\%) not having $\mathrm{BPb}$ above $5 \mu \mathrm{g} / \mathrm{dL}$ [31-34].

Despite its numerous applications in many countries, the IEUBK model has not yet been used in Malawi or in any other country in Africa, prior to this study. Therefore, it was necessary to first evaluate the applicability of the model in Malawi by assessing the agreement, if any, between the measured and predicted $\mathrm{BPb}$ values. Indeed, the applicability of the IEUBK has been assessed in a number of countries including, among others, the USA [32], Belgium [31], China [35,36], and Australia [37]. The study approach in these countries has largely been based on the comparison of the predicted $\mathrm{BPb}$ data with the $\mathrm{BPb}$ data measured in cross-sectional studies. Similarly, in this study, BPb data was obtained from children in Blantyre through a descriptive cross-sectional epidemiological study and was compared with $\mathrm{BPb}$ predicted from the model based on $\mathrm{Pb}$ levels in various environmental media. Furthermore, a risk assessment was conducted based on these data. However, since risks are assessed by correlating the predicted $\mathrm{BPb}$ values with potential health effects that 
are observed at various $\mathrm{BPb}$ ranges [38], the risk assessment procedure for $\mathrm{Pb}$ does not follow the typical risk assessment process for carcinogenic and non-carcinogenic substances, which utilize cancer slope factors and reference doses, respectively.

\section{Methodology}

\subsection{Study Setting and Study Population}

Blantyre City is divided into six health catchment areas, which are served by six main health centers. These areas are Machinjiri, Chilomoni, Ndirande, Limbe, Zingwangwa, and Bangwe. Blantyre has many residential, commercial, and industrial areas, with some of the residential areas located in close proximity to industrial sites. However, there are no mining activities or $\mathrm{Pb}$ smelters close to Blantyre City, and there are no known industrial activities that can result in occupational and/or environmental exposure to $\mathrm{Pb}$.

The study population included children between 1-6 years of age, who had lived at the residence for at least six months prior to enrolment. The population of the age group 1-6 years in Blantyre can be estimated to be over 100,000 [39]. Children that were still under breast-feeding were excluded from the study.

\subsection{Recruitment of Children}

Ethics approval was obtained from the University of the Witwatersrand Committee for Research on Human Subjects (No. M120662) as well as from Malawi College of Medicine Research Ethics Committee (COMREC) (No. P.09/12/1282). The sample size was calculated based on Pb exposure from Botswana [40] due to its similar socio-economic characteristics and climate. Using statistical parameters from this study and an equation for calculating sample sizes for prevalence studies [41], the minimum sample size was calculated to be 120 .

$$
n=\frac{Z_{\alpha} \sigma^{2}}{d^{2}} .
$$

where $n=$ number of children.

$Z_{\alpha}=$ standard normal deviate corresponding to a 2-sided level of significance of $5 \%=1.96$.

$\sigma=$ standard deviation of $\mathrm{Pb}$ level from previous study $=5.6 \mu \mathrm{g} / \mathrm{dL}$.

$d=$ level of precision $=1 \mu \mathrm{g} / \mathrm{dL}$.

$n=120$.

In order to account for an estimated refusal or non-response rate of $50 \%$, the targeted number of children in the study was 240, comprising of 40 children from each of the 6 health catchment areas of Blantyre. Therefore, after introducing the project to community leaders, 40 names of eligible children were randomly chosen from the community nurses' and health surveillance assistants' (HSAs) register in each health catchment area. Subsequently, study information sheets written in both English and the vernacular Chichewa were given to the children's parents or guardians. Only individuals that consented to take part in the study were enrolled.

\subsection{Sampling and Sample Collection 3.1. Blood}

One millimeter venous samples of whole blood were drawn into Vacutainer tubes with techniques designed to ensure minimal $\mathrm{Pb}$ contamination, as is recommended in the literature [42]. These samples were stored at $4-6{ }^{\circ} \mathrm{C}$ at the College of Medicine laboratory awaiting transportation to Lancet Laboratories in South Africa for analysis.

\subsubsection{Food and Water}

Samples of the most commonly consumed foods as determined by the food frequency questionnaire (FFQ) were acquired from the market in the health catchment area concerned, as recommended in the WHO guidelines [43]. Wherever necessary, the food was prepared by a few participating women from each catchment area using the most common methods of preparation. The foods were then stored at $-20^{\circ} \mathrm{C}$ at the College of Medicine cold room. 
A water $(250 \mathrm{~mL})$ sample was drawn from the homes of the participants at any random time of the day, as is commonly practiced in the literature [44]. The samples of water were then stored at $-20^{\circ} \mathrm{C}$ at the College of Medicine cold room.

\subsubsection{House Dust and Soil}

Floor dust samples were collected from the children's bedroom wherever possible or in the lounge, using a broom or brush from each particular home. Use of broom or brush for sampling dust is a method that is found in the literature [45] together with wipe sampling methods and use of vacuum cleaners [46,47]. In some cases, samples of dust were also obtained from the school that the children were attending. The dust samples were not touched with bare hands to avoid contamination, as is recommended by the US Department of Housing and Urban Development (HUD) [48].

Two samples of surface soil from the children playground at home were collected into a sample container ( $60 \mathrm{~mL}$ bottles) by a scoop. In some cases, samples of soil were also collected from the playground at the school that the children were attending.

\subsubsection{Food Consumption Data}

Food consumption data was collected using a seven-day food frequency questionnaire (FFQ) that was adopted from the Birth-to-Twenty cohort study and the Malawi Second Integrated Household Survey (IHS) questionnaire [49]. Food conversion factors were adopted from the South African Medical Research Council (MRC) Food Photo manual [50] and the Malawi Third IHS 2010/11 Data [51].

\subsection{Laboratory Analysis of Lead in Various Samples}

Blood samples were analyzed at Lancet Laboratories in Johannesburg, South Africa, whereas dust, soil, food, water, paint, and toy samples were analyzed at Protechnik Laboratories (a Division of Armscor SOC Ltd.in Pretoria, South Africa, both being accredited commercial laboratories that participate in national and international quality control programs. Quality assurance was maintained by use of these certified laboratories as well as appropriate certified reference materials.

\subsubsection{Lead in Blood}

Whole blood samples were diluted ten times by adding $100 \mu \mathrm{L}$ of each blood sample to $900 \mu \mathrm{L}$ of diluent $(10 \%$ Triton X-100). Analysis was performed on a Varian SpectrAA 220Z Graphite Furnace Atomic Absorption Spectroscopy (GFAAS). The instrument was calibrated with calibration standards prepared in sheep blood for matrix matching. The detection limit (three times standard deviation of all blank samples) for $\mathrm{Pb}$ in whole blood was $1 \mu \mathrm{g} / \mathrm{dL}$, while the uncertainty of reading was $14.5 \%$.

\subsubsection{Lead in Food and Water}

A known weight (approximately $2 \mathrm{~g}$ ) of the food sample was dry-ashed at $420{ }^{\circ} \mathrm{C}$. Ashed samples were dissolved in $10 \mathrm{~mL} 0.25 \% \mathrm{HNO}_{3}$. The $\mathrm{Pb}$ concentrations were then determined by ICP-MS. Water samples were acidified before determination of $\mathrm{Pb}$ using an ICP-MS method based on NIOSH 7300 and ISO 15202-3.

\subsubsection{Lead in House Dust and Soil}

House dust and soil samples were digested in nitric and perchloric acids, and after filtration, the solutions were analyzed for Pb using an ICP-MS method based on National Institute of Occupational Safety and Health (NIOSH) 7300 and ISO 15202-3. 


\subsection{Data Processing and Analysis}

\subsubsection{Data Entry}

Data were entered into Microsoft Excel 2007 spreadsheets, cleaned, and then transferred to STATA version 12 statistical package spreadsheets for analyses. Descriptive statistics including means and standard deviations were calculated for all the $\mathrm{Pb}$ concentrations.

\subsubsection{Prediction of Blood Lead from Food, Water, House Dust, and Soil Using the} IEUBK Model

In order to match the laboratory analysis of $\mathrm{Pb}$ in food, which were based on dry weight, moisture content was corrected using the following Equation (2) [52]:

$$
I R_{D r y}=I R \frac{(100-M)}{100}
$$

where $I R_{D r y}$ is the average consumption rate of the food item on a dry basis, $I R$ is the average consumption of the food item as given in the FFQ and $M$ is the moisture content of the food.

The calculated $I R_{D r y}$ could then be used to calculate the dietary intake (dose), which was subsequently used in the IEUBK model. For food, the IEUBK model default bioavailability of $50 \%$ (as recommended for the model) and a 31\% value from the literature [53] were used in the present study, while for soil a default bioavailability of $30 \%$ was used.

\subsubsection{Assessment of Model Performance}

Model performance was assessed by calculating the modelling efficiency (ME), the Nash-Sutcliffe efficiency (NSE), the Root Mean Deviation (RMD), the ' $95 \%$ limits of agreement method', and by using the paired student's $t$ test. Since each one of model performance criteria emphasizes on different aspects of model performance, it is important to use a combination and not just one criterion.

ME compares the efficiency of the model to the efficiency of describing the data using the mean of the observations. In other words, the ME indicates whether the model describes the data better than simply the average of the measurements. The ME is calculated as shown in Equation (3):

$$
M E=\frac{\sum_{i=1}^{n}\left(O_{i}-O_{A v}\right)^{2}-\sum_{i=1}^{n}\left(P_{i}-O_{i}\right)^{2}}{\sum_{i=1}^{n}\left(O_{i}-O_{A v}\right)^{2}}
$$

where $P_{i}$ is the predicted $\mathrm{BPb}$ value, $O_{i}$ is the observed or measured $\mathrm{BPb}$ value, $O_{A v}$ is the average of the observed values, and $n$ is the number of values [54]. The values of $M E$ range from -1 to +1 , where a positive value of $M E$ indicates that the predicted values provide a better trend than the mean of observed values, while a negative value of $M E$ indicates that the predicted values do not describe the trend better than the mean of observed values [55].

The NSE is a "statistic that determines the relative magnitude of the residual variance compared to the measured data variance" [43]. It can be computed using Equation (4):

$$
N S E=1-\frac{\sum_{i=1}^{n}\left(O_{i}-P_{i}\right)^{2}}{\sum_{i=1}^{n}\left(O_{i}-O_{a v}\right)^{2}}
$$

where $O_{i}$ is the observed or measured $\mathrm{BPb}$ value at a particular place or time $i, P_{i}$ is the predicted $\mathrm{BPb}$ value at a particular place or time $\mathrm{I}$, and $O_{A v}$ is the average of the observed values. NSE indicates how well the plot of measured versus predicted data fits the '1:1 line'. NSE values range between $-\infty$ and 1.0, with an optimal value of 1 , where "values between 0 and 1 are generally viewed as acceptable levels of performance, whereas values $<0.0$ indicates that the mean observed value is a better predictor than the simulated value, which indicates unacceptable performance" [56]. 
The RMD is a parameter that evaluates bias in the model, with values close to 0 , indicating absence of bias [35]. It can be calculated using Equation (5):

$$
R M D=\frac{100}{O_{i}} \sum_{i=1}^{n} \frac{P_{i}-O_{i}}{n}
$$

The $95 \%$ agreement method is a simple statistical method in which the difference between measurements on the same individual by two methods is plotted against the mean of the two measurements. In this method, the $95 \%$ of differences between measurements by two methods are expected to lie between the mean difference \pm 2 standard deviations [57]. Finally, the paired student's $t$ test determines if there is a significant difference in the means of independent paired data.

\subsubsection{Assessment of Potential Effects of Lead}

Potential health effects of $\mathrm{Pb}$ were assessed in terms of measured $\mathrm{BPb}$ concentrations using cut-off points or thresholds for $\mathrm{BPb}$ concentrations for various health outcomes, which include reduction of IQ $(5 \mu \mathrm{g} / \mathrm{dL})$, gastro-intestinal effects $(60 \mu \mathrm{g} / \mathrm{d}) \mathrm{L}$, and anaemia $(70 \mu \mathrm{g} / \mathrm{dL})[58]$.

\section{Results}

\subsection{Concentrations of Lead in Food, Water, House Dust, and Soil}

The concentrations of $\mathrm{Pb}$ in food ranged from 0.01 in chicken to $3.3 \mathrm{mg} / \mathrm{kg}$ in potato chips. All water samples, on the other hand, contained $\mathrm{Pb}$ in amounts that were below the detection limit of $0.000018 \mathrm{mg} / \mathrm{L}$. The concentrations of $\mathrm{Pb}$ in house dust ranged from 2.3 to $265 \mathrm{mg} / \mathrm{kg}$, with an outlying figure of $17,179 \mathrm{mg} / \mathrm{kg}$. Apart from the latter outlying figure, the concentrations of $\mathrm{Pb}$ in house dust in most homes were much lower than the USA limit of $400 \mathrm{mg} / \mathrm{kg}$ for $\mathrm{Pb}$ in soil in playgrounds. The concentration of $\mathrm{Pb}$ in soil ranged from 1.5 to $482 \mathrm{mg} / \mathrm{kg}$, with only one sample of soil containing Pb above the limit of $400 \mathrm{mg} / \mathrm{kg}$. Therefore, it can be concluded that in general, the concentrations of $\mathrm{Pb}$ in house dust and playground soil in many homes in Blantyre were very low.

\subsection{Predictions by the IEUBK Model in Comparison with Measured Blood Lead}

Since $\mathrm{Pb}$ in air was not measured in this study and also since the concentrations for $\mathrm{Pb}$ in water were below detection limit, it was only possible to use the $\mathrm{Pb}$ levels assessed in food, soil, and house dust. Using these latter values, in addition to the default and published values for bioavailability of $\mathrm{Pb}$ from these sources, it was possible to predict the $\mathrm{BPb}$ levels resulting from exposure to $\mathrm{Pb}$ from the aforementioned three sources. For example, using the default bioavailability value for $\mathrm{Pb}$ in food $(50 \%)$ and a default bioavailability value for $\mathrm{Pb}$ in soil $(30 \%)$, the obtained predicted values of $\mathrm{BPb}$ ranged from 10.5 to $39.2 \mu \mathrm{g} / \mathrm{dL}$, with a geometric mean of $12.5 \mu \mathrm{g} / \mathrm{dL}$, compared to the measured $\mathrm{BPb}$ values, which ranged from 2.0 to $50.4 \mu \mathrm{g} / \mathrm{dL}$, with a geometric mean of $6.5 \mu \mathrm{g} / \mathrm{dL}$. The comparison of the geometric means of predicted $\mathrm{BPb}$ with the geometric means of observed $\mathrm{BPb}$ segregated by age of children is presented in Figure 1.

It is important to note that the IEUBK model is designed to predict $\mathrm{BPb}$ values below $30 \mu \mathrm{g} / \mathrm{dL}$ for individuals, as well as geometric means for populations. Indeed, since $\mathrm{BPb}$ values above $30 \mu \mathrm{g} / \mathrm{dL}$ would be considered very high even among occupationally exposed adults, it was not envisaged before the initiation of the study that children would have $\mathrm{BPb}$ values above this value. Therefore, two BPb values above $30 \mu \mathrm{g} / \mathrm{dL}$ ( 37 and $52 \mu \mathrm{g} / \mathrm{dL}$ ) were removed in the calculation of the averages, which also removed the skewness of the data brought by values above $30 \mu \mathrm{g} / \mathrm{dL}$. However, it needs to be pointed out that since only two children had BPb levels above this limit $30 \mu \mathrm{g} / \mathrm{dL}$, the removal of these figures is expected to have minimal or negligible impacts on the results. 


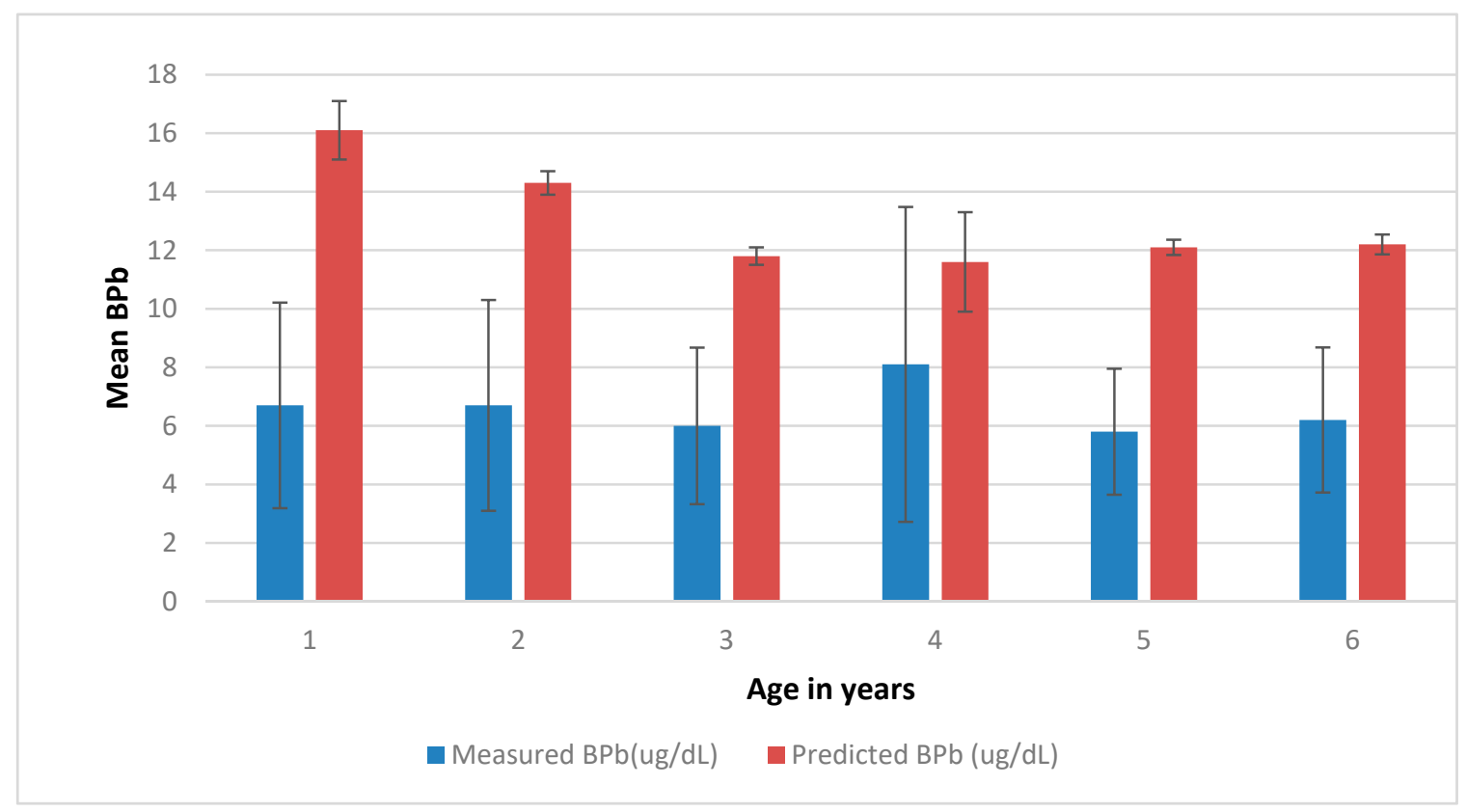

Figure 1. Comparison of the geometric means predicted and mean observed $\mathrm{BPb}$ against age (for $50 \%$ food bioavailability and a default $30 \%$ soil bioavailability).

The ME of -2.24 , NSE of -3.30 , RMD of 88 , and the students' $t$-test have indicated poor agreement between the predicted and measured $\mathrm{BPb}$ values, and that the measured mean was a better description than the values predicted by the model. Subsequently, it could be said that there was significant difference between measured and predicted $\mathrm{BPb}$ values when a default bioavailability of $50 \%$ for $\mathrm{Pb}$ in food and $30 \%$ for $\mathrm{Pb}$ in soil were used, where the predicted values were on average two-fold higher than the measured values.

Furthermore, using the $95 \%$ agreement method, the averages of the measured and predicted $\mathrm{BPb}$ values were plotted against the differences between predicted and measured values for each individual (Figure 2 below). The differences between predicted and measured values have a mean of $5.96 \mu \mathrm{g} / \mathrm{dL}$ and a standard deviation of 3.65. Therefore, as the $95 \%$ limits are $5.96 \pm 1.96 \times 3.65$ (i.e., 13.1 and -1.11 ), it can be concluded that for $95 \%$ of children, prediction by the IEUBK model would be between about $1 \mu \mathrm{g} / \mathrm{dL}$ less and about $13 \mu \mathrm{g} / \mathrm{dL}$ higher than measured values [59]. Since the critical value for BPb in children is only $5 \mu \mathrm{g} / \mathrm{dL}$, the model would tend to over-predict most $\mathrm{BPb}$ values when $50 \%$ dietary $\mathrm{Pb}$ bioavailability is used. This over-prediction is consistent with the results displayed in Figure 1 above.

On the other hand, using a bioavailability of $31 \%$ for $\mathrm{Pb}$ in food obtained from the literature and a default bioavailability of $30 \%$ for $\mathrm{Pb}$ in soil, the predicted $\mathrm{BPb}$ values obtained have ranged from 6.8 to $33.9 \mu \mathrm{g} / \mathrm{dL}$, with geometric mean of $8.30 \mu \mathrm{g} / \mathrm{dL}$. In comparison, measured $\mathrm{BPb}$ values ranged from 2.0 to $50.4 \mu \mathrm{g} / \mathrm{dL}$, with a geometric mean of $6.5 \mu \mathrm{g} / \mathrm{dL}$. The comparison of the geometric means of predicted $\mathrm{BPb}$ with the geometric means of observed $\mathrm{BPb}$ segregated by age of children is provided in Figure 3.

In this instance as seen in Figure 3, the NSE of -0.3 , and a paired $t$-test values have indicated poor agreement between the predicted and measured $\mathrm{BPb}$ values. On the other hand, an RMD value of 25.7 indicated slight bias in the model and an ME value of +0.49 has shown that the predicted values are better indicators of $\mathrm{BPb}$ levels than the mean of measured $\mathrm{BPb}$. As such, the ME and RMD values have provided an acceptable agreement between the two sets of values, where the predicted values were on average only 1.3-fold higher than the measured $\mathrm{BPb}$ values. 


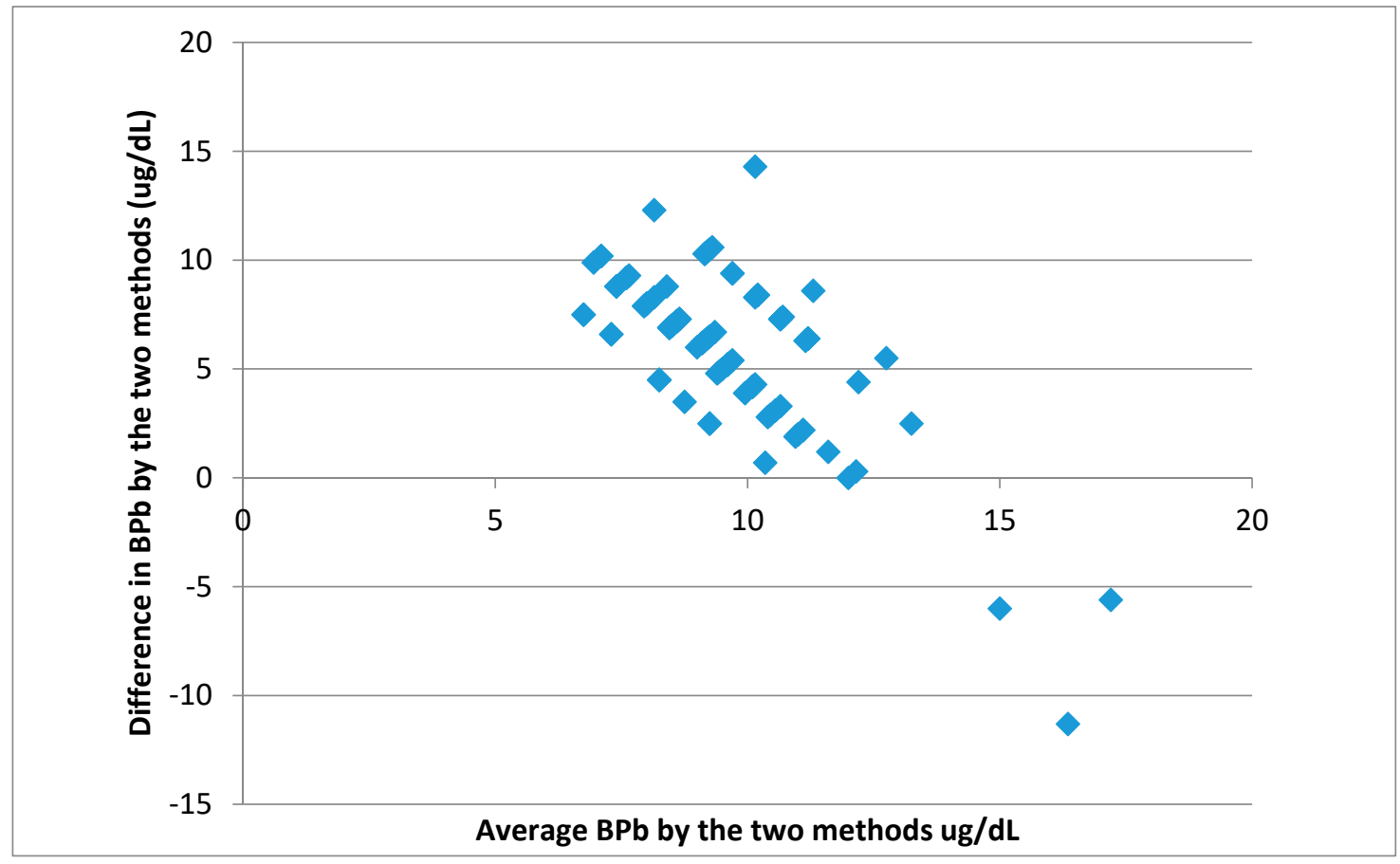

Figure 2. A plot of the average of the measured and predicted $\mathrm{BPb}$ against the differences between predicted and measured $\mathrm{BPb}$ values (for $50 \%$ food bioavailability).

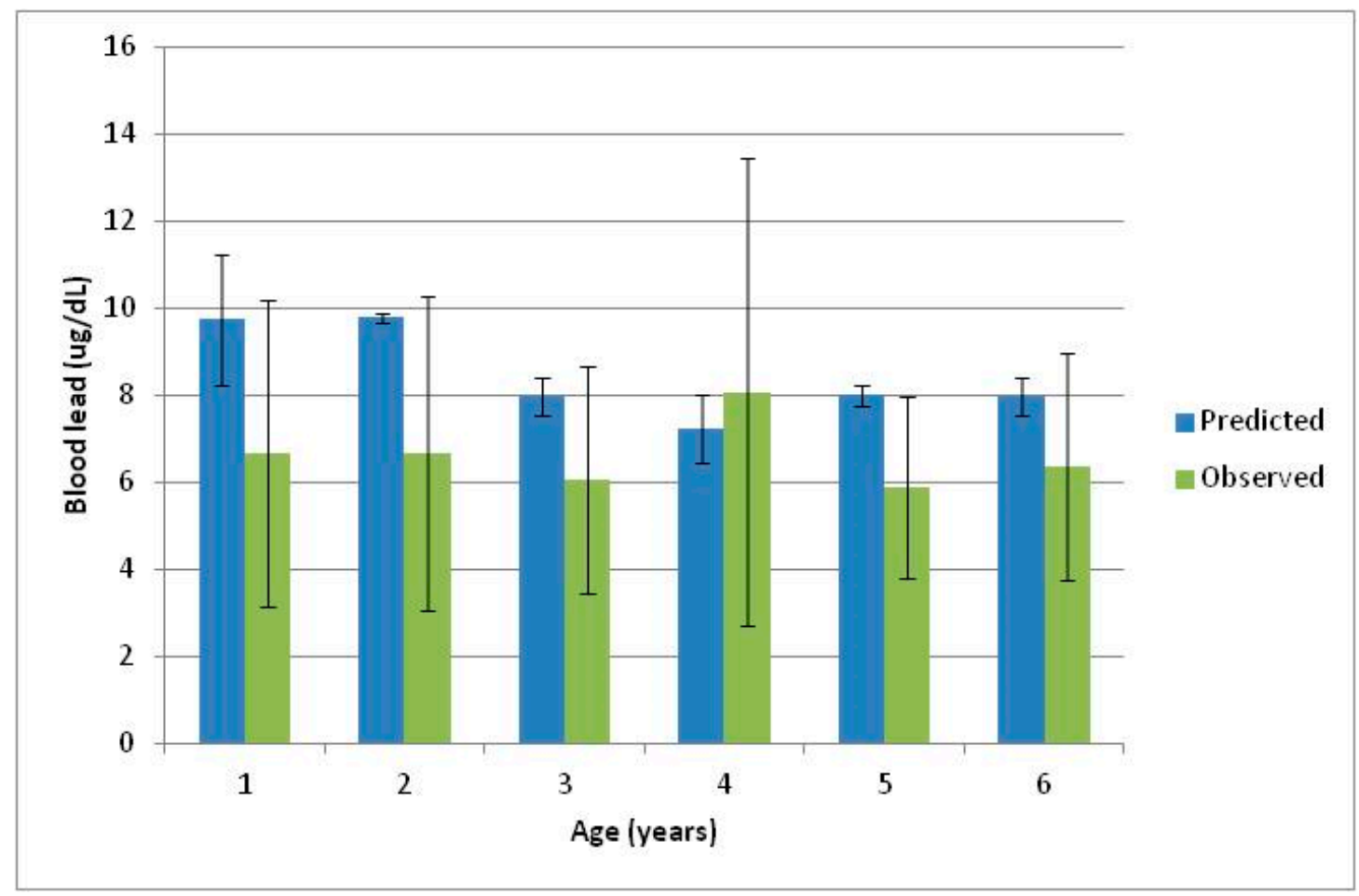

Figure 3. Comparison of the geometric means predicted and mean observed blood $\mathrm{Pb}$ against age (for $31 \%$ food $\mathrm{Pb}$ bioavailability and a default $30 \%$ soil $\mathrm{Pb}$ bioavailability).

The differences between predicted and measured values have a mean of $1.74 \mu \mathrm{g} / \mathrm{dL}$ and a standard deviation of 3.44 (Figure 4). Therefore, as the $95 \%$ limits are $1.74 \pm 1.96 \times 3.44$ (i.e., -5.0 and 8.48 ), it can be concluded that for $95 \%$ of children, prediction by the IEUBK model would be between about $-5 \mu \mathrm{g} / \mathrm{dL}$ less and about $8 \mu \mathrm{g} / \mathrm{dL}$ higher than measured 
values. Predictions of $5 \mu \mathrm{g} / \mathrm{dL}$ less or $8 \mu \mathrm{g} / \mathrm{dL}$ higher than measured values may result in misallocation of a child's BPb, especially since the $\mathrm{BPb}$ level of action is only $5 \mu \mathrm{g} / \mathrm{dL}$. However, there is much better agreement between predicted and measured BPb than in the case when $50 \%$ dietary $\mathrm{Pb}$ bioavailability was used, which indicates that the value of bioavailability used in the model can have a significant impact on the level of agreement between predicted and measured $\mathrm{BPb}$ values.

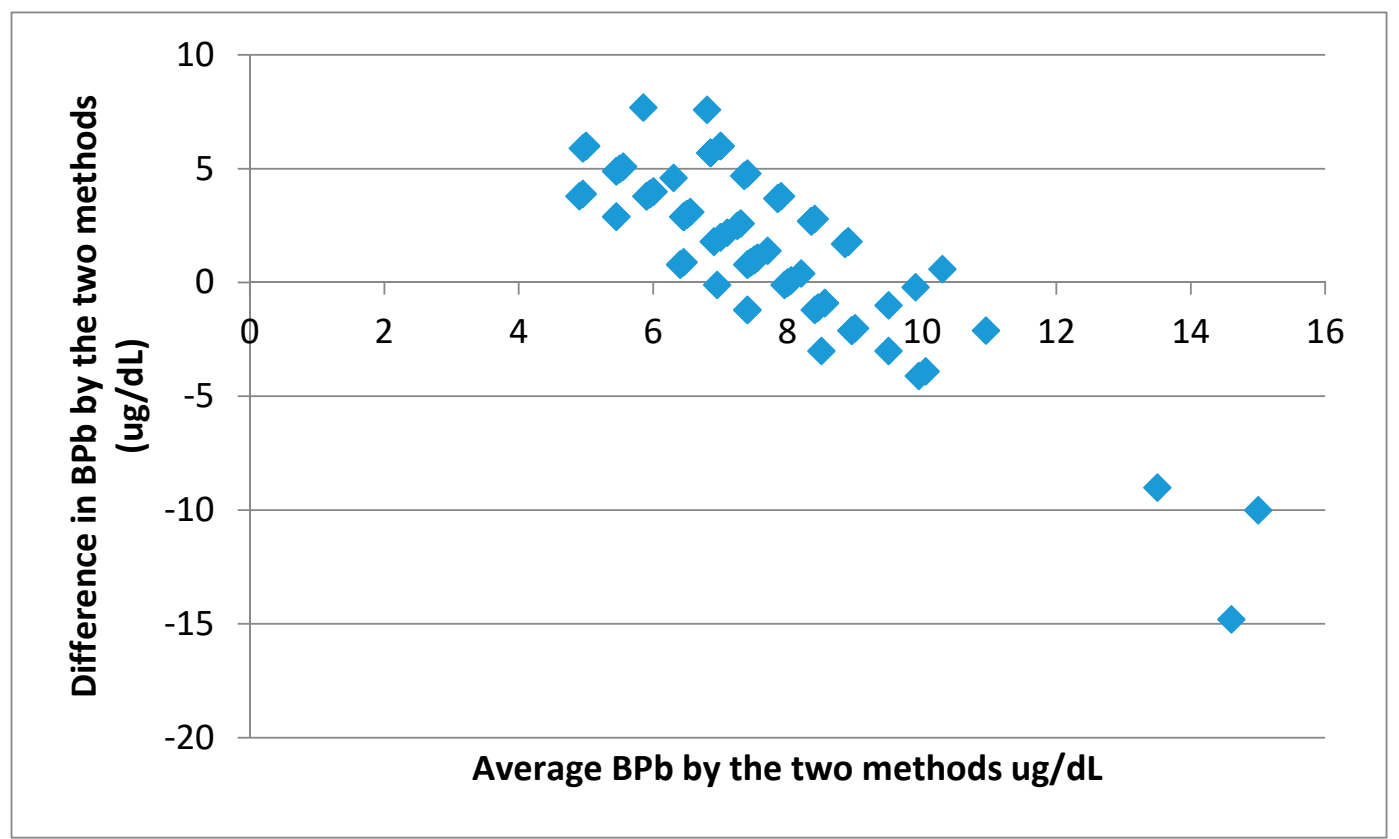

Figure 4. A plot of the average of the measured and predicted $\mathrm{BPb}$ against the differences between predicted and measured $\mathrm{BPb}$ values (for $31 \%$ food $\mathrm{Pb}$ bioavailability and a default $30 \%$ soil $\mathrm{Pb}$ bioavailability).

\subsection{Potential Health Effects of Blood Lead}

There were 152 subjects ( 82 males and 70 females), aged between one to six years (average $4.07 \pm 1.59$ ). Measured BPb values ranged from $2.0-50.4 \mu \mathrm{g} / \mathrm{dL}$, with an average of $6.9 \pm 5.3 \mu \mathrm{g} / \mathrm{dL}$. Approximately, $72 \%$ of the children had high BPb, i.e., $\mathrm{BPb} \geq 5 \mu \mathrm{g} / \mathrm{dL}$ and $22.8 \%$ had $\mathrm{BPb} \geq 10 \mu \mathrm{g} / \mathrm{dL}$. These results show that almost $72 \%$ of the children may be at risk of suffering from IQ reduction. On the other hand, none of the children had $\mathrm{BPb}$ levels above $60 \mu \mathrm{g} / \mathrm{dL}$, and hence the risk of suffering from $\mathrm{Pb}$-induced anaemia and gastro-intestinal effects were non-existent.

Depending on the bioavailabilities used, BPb ranged from approximately 7 to $15.5 \mu \mathrm{g} / \mathrm{dL}$, indicating that the model would predict that all the children would be at risk of suffering from IQ reduction.

\section{Discussion}

Statistical analyses performed in this study have shown different levels of agreement between measured and predicted $\mathrm{BPb}$ depending on the bioavailability used. The IEUBK model was validated using some default bioavailability values and their use is recommended. Therefore, the present study used these default bioavailability parameters. However, it is important to note that these values were obtained from studies in America and Europe, and therefore may not be appropriate for all children and for every site-specific application such as in Malawi. Bioavailability is known to be affected by site-specific soil properties such as soil type, $\mathrm{pH}$, and cation-exchange capacity [60], as well as nutritional status of the subjects [61] and the type of food matrix [62]. However, using default bioavailability values, close agreement was achieved in China [35], while the model was over-predictive in Mexico [63], USA [32], and Belgium [31]. Better agreement between 
measured and predicted $\mathrm{BPb}$ values are anticipated if site-specific bioavailabilities were utilized, as was achieved in Kazakhstan [24]. Since the determination of bioavailabilities require independent and dedicated studies, their determination is highly recommended in any future use of the model in Malawi.

The less than perfect agreement between measured and predicted data can also be attributed to a number of factors. Firstly, due to lack of more reliable food consumption data, the food consumption data used was obtained using a seven-day FFQ. Although the food consumption data was based on local data, and therefore can be said to more relevant than national data, the data was obtained from only 152 participants, which is much smaller than the sample sizes used in typical food consumption surveys [64]. There was need for food consumption data from independent and dedicated food consumption surveys repeated over time to address issues of intra-and inter-individual variabilities [65]. In addition, since the FFQ method requests participants to recall the foods consumed in the past seven days including types, amounts, and frequency, food intake assessments obtained through this retrospective approach are prone to errors that arise from the use of memory and also from recall bias [66]. In that regard, more reliable food consumption data can be obtained using prospective dietary assessment methods such as duplicate portion studies or food diaries involving larger numbers of participants and covering longer periods of time $[67,68]$. The prospective food intake assessment methods could not be used in the present study because of cost and logistical reasons.

In addition to the use of recommended (default) bioavailability values, the study used bioavailabilities from the literature. Despite the lack of agreement between measured $\mathrm{BPb}$ and predicted $\mathrm{BPb}$, calculations from the model and the relatively high levels of $\mathrm{Pb}$ in food in relation to the high food consumption rates seem to indicate food is the major contributor to the high $\mathrm{BPb}$ in children. Indeed, investigations in the literature have also shown that food has been the major contributor to BPb in China (83.4\%) [35] and Belgium (over 75\%) [31]. Therefore, the present results and those presented in the literature reiterate the importance of food as a major source of $\mathrm{BPb}$, and hence further investigations are recommended to elucidate the origins of high $\mathrm{Pb}$ content in food. Dietary $\mathrm{Pb}$ originates from environmental sources such as soil, water, and air, as well as food processing, food handling, and food packaging [69]. Environmental $\mathrm{Pb}$ food contamination may result from $\mathrm{Pb}$ that is strongly adsorbed to soil and organic particles [70]. The $\mathrm{Pb}$ can persist for years and be later absorbed in crops through the roots and translocated to aerial parts of the plant. Lead contamination of food can also result from use of contaminated utensils/apparatus for food preparation or storage as well as packaging materials [71]. Therefore, there is a need to investigate the contribution of these sources to dietary $\mathrm{Pb}$ in Blantyre Malawi.

The IEUBK model could also show that soil and house dust are minor contributors $(11.2 \%)$. These results were in agreement with those reported for China (15\%) [35], but in disagreement with those reported for Australia (54\%) [38]. Indeed, outdoor soil has been reported to be a reservoir of legacy $\mathrm{Pb}$ from multiple anthropogenic sources, resulting in contemporary $\mathrm{Pb}$ exposure through soil-air dust- home (or school) pathways [72]. Exposure to this legacy soil $\mathrm{Pb}$ primarily through re-suspended dust is subject to climatic and seasonal factors such as rainfall, wind, and humidity.

In contrast to soil, water samples in the present study were shown to contain undetectable amounts of $\mathrm{Pb}$, and hence it could be said that contribution of water to $\mathrm{BPb}$ was minimal.

While the predicted $\mathrm{BPb}$ data indicates that all children in Blantyre have high $\mathrm{BPB}$ levels $(6.8$ to $39.2 \mu \mathrm{g} / \mathrm{dL})$, the measured $\mathrm{BPb}$ values have shown that $71.7 \%$ of children have $\mathrm{BPb} \geq 5 \mu \mathrm{g} / \mathrm{dL}$ and $23 \%$ have $\mathrm{BPb} \geq 10 \mu \mathrm{g} / \mathrm{dL}$. Similar investigations conducted using measured $\mathrm{BPb}$ values in other countries in the region have also shown high levels of exposure to $\mathrm{Pb}$ among children. These have included Botswana, where $31 \%$ of the children had $\mathrm{BPb}$ levels $\geq 10 \mu \mathrm{g} / \mathrm{dL}$ [40] and South Africa, where $78 \%$ of children had $\mathrm{BPb} \geq 10 \mu \mathrm{g} / \mathrm{dL}$ [73]. However, it needs to be pointed out that the studies conducted in Botswana and South Africa were conducted soon after the introduction of regulations on leaded petrol in these countries, 
whereas the present study has been conducted about ten years after the introduction of these regulations. On the other hand, levels of $\mathrm{BPb}$ in the present study were much higher than those reported in countries from other regions such as China, where only $1.32 \%$ of children had $\mathrm{BPb}$ above $5 \mu \mathrm{g} / \mathrm{dL}$ [74].

The IEUBK model is designed to predict $\mathrm{BPb}$ levels from exposure to $\mathrm{Pb}$ from a limited number of external sources including food, water, air, soil, and house dust due to the fact that the intake rates from these external sources are possible to assess. For the same token, it is therefore not possible to use this model to predict $\mathrm{BPb}$ from external sources such as cosmetics, children's toys, (traditional) medicines, and paint as the intake or exposure rates to $\mathrm{Pb}$ from these sources are not practically possible to assess. Although exclusion of $\mathrm{Pb}$ exposure from these sources has not affected the performance of the model in China [35], significant contributions from these sources may result in poor agreement between measured $\mathrm{BPb}$ and $\mathrm{BPb}$ predicted from the model, as was observed by von Lindern et al. [32]. In Mexico, the main source of variability was reported to be glazed ceramic pottery [63]. The lead-glazed pottery, direct exposure to $\mathrm{Pb}$ from paint chips, toys, cosmetics, and medicine are miscellaneous sources that need to be well-characterized in separate risk assessments of these individual products.

Although cross-sectional study designs were successfully used in Mexico [63], Belgium [31], Australia [37], and China [35] to assess the applicability of the model in their countries, the present study may have been affected by the use of this study design, since it only captures a snapshot of exposure levels at a particular time, on the assumption that levels of exposure to each individual remain constant with time. Contrary to the assumption of constant environmental $\mathrm{Pb}$ concentrations, however, levels of $\mathrm{Pb}$ in dust, soil, and food, may vary with time, and thereby affect the cumulative levels of $\mathrm{BPb}$. Indeed, $\mathrm{Pb}$ in the blood of each child was affected by the cumulative exposure levels, which were changing with time. These variations may have significantly contributed to the poor agreement between predicted and measured $\mathrm{BPb}$ values. In contrast to cross-sectional studies, a longitudinal study design, which captures the variations in exposure levels, may be recommended for future studies, where measurements of $\mathrm{Pb}$ in the same participants and their environments may be taken periodically over time. Indeed, in their discussion on the validation strategies for the IEUBK model, the USEPA [75] acknowledged the importance and 'usefulness' of longitudinal studies, but also recognized the role of cross-sectional studies because of the time and financial constraints associated with longitudinal studies. It is important to note, however, that while Gulson et al. [76] used longitudinal data in Australia to show good agreement between predicted and measured $\mathrm{BPb}$, use of longitudinal data in the USA by von Lindern et al. [32] resulted in over-prediction of the model. This emphasizes the importance of other factors to the accuracy of the model, in addition to the study design.

The study did also not consider the contribution of maternal $\mathrm{Pb}$ due to lack of data on maternal $\mathrm{Pb}$ in Malawi. However, since $\mathrm{Pb}$ can easily be transferred through the placenta [77] and through breast milk [78] maternal $\mathrm{Pb}$ can be a significant source of Pbin children. In the present study, the effect of maternal $\mathrm{Pb}$ was ameliorated by the exclusion of children that were still on breast milk at the time of the study. This notwithstanding, the contribution of the reservoirs of bone $\mathrm{Pb}$ that was acquired in utero as well as from breast milk may still have an effect on BPb levels for many years [79,80]. Finally, concentrations of $\mathrm{Pb}$ in air were not measured, on the assumption that banning of leaded petrol has reduced its concentrations in air to negligible levels [81].

\section{Conclusions}

This study aimed to utilize the IEUBK model to convert the concentrations of $\mathrm{Pb}$ in food, water, and environmental media $\mathrm{BPb}$ concentrations in children aged between one and six years. There was less than perfect agreement between measured and predicted $\mathrm{BPb}$ values in this study because of a number of issues and challenges. Firstly, statistical analyses indicated different levels of agreement between measured and predicted $\mathrm{BPb}$ depending on the bioavailability used. The present study used recommended (default) bioavailability 
parameters from studies in America and Europe, which may not be appropriate for Malawi. The application of the IEUBK in Malawi also needs more reliable food consumption data, which were not available at the time of the study.

The IEUBK model is designed to predict $\mathrm{BPb}$ levels from exposure to $\mathrm{Pb}$ from a limited number of external sources including food, water, air, soil, and house dust and not from other sources such as cosmetics, children's toys, (traditional) medicines, and paint where the exposure or intake rates are impractical or difficult to assess. Significant contributions from these sources would result in poor agreement between measured $\mathrm{BPb}$ and $\mathrm{BPb}$ predicted from the model.

The cross-sectional design used in this study may not adequately capture the varying levels of $\mathrm{Pb}$ in dust, soil, and food, which affect the cumulative levels of $\mathrm{BPb}$. Therefore, more accurate predictions from the IEUBK model may be expected from longitudinal data, rather than cross-sectional data.

In the end, the IEUBK model did not yield satisfactory results and its use in Malawi is contingent on proof of its applicability using, among others, site-specific bioavailability values and food consumption data that accounts for inter- and intra-individual variabilities. Nevertheless, both predicted and measured $\mathrm{BPb}$ indicate that children in Blantyre are exposed to high levels of $\mathrm{Pb}$. Therefore, further studies are needed to establish the origin of $\mathrm{Pb}$ as well as methods for reducing it in all areas of Blantyre.

Author Contributions: Conceptualization, W.U. and M.G.; development of study protocol W.U., W.U. and M.G.; data collection, W.U.; data analysis, W.U.; writing-original draft preparation, W.U. and M.G.; writing—review and editing, W.U. and M.G.; project administration, W.U.; funding acquisition, W.U. and M.G.; project supervision, M.G. All authors have read and agreed to the published version of the manuscript.

Funding: This research (or [WU]) was supported by the Consortium for Advanced Research Training in Africa (CARTA). CARTA is jointly led by the African Population and Health Research Center and the University of the Witwatersrand and funded by the Carnegie Corporation of New York (Grant No-G-19-57145), Sida (Grant No: 54100113), Uppsala Monitoring Centre and the DELTAS Africa Initiative (Grant No: 107768/Z/15/Z). The DELTAS Africa Initiative is an independent funding scheme of the African Academy of Sciences (AAS)'s Alliance for Accelerating Excellence in Science in Africa (AESA) and supported by the New Partnership for Africa's Development Planning and Coordinating Agency (NEPAD Agency) with funding from the Wellcome Trust (UK) and the UK government. The study was also supported by the National Institute for Occupational Health (NIOH) in South Africa, a division of the National Health Laboratory Service (NHLS) as well as the Malawi Polytechnic, a constituent College of the University of Malawi. The statements made and views expressed are solely the responsibility of the Fellow.

Institutional Review Board Statement: The study was conducted according to the guidelines of the Declaration of Helsinki. Ethical approval was sought from the University of the Witwatersrand Committee for Research on Human Subjects (No. M120662, approved 29 June 2012) as well as from Malawi College of Medicine Research Ethics Committee (COMREC) (No. P.09/12/1282, approved 4 October 2012).

Informed Consent Statement: Informed consent was obtained from all subjects involved in the study. None of the participants can be identified in the study.

Data Availability Statement: More data on the study can be accessed at http:/ / wiredspace.wits.ac. $\mathrm{za} /$ xmlui/bitstream/handle/10539/22245/Thesis\%20Wells\%20Utembe\%20Final\%20resubmission\% 2015\%20August\%202016.pdf? sequence=1\&isAllowed =y (accessed on 8 July 2021).

Acknowledgments: We also acknowledge L Alfazema's substantial support to the project. We are also grateful to the Officers-in-Charge, Community Nurses, and Health Surveillance Assistants at Chilomoni Health Centre, Bangwe Health Centre, Machinjiri Health Centre, Limbe Health Centre, Ndirande Health Centre, and Zingwangwa Health Centre for the assistance in participant recruitment and collection of specimens. We would also like to acknowledge Staff at Lancet Laboratories in Johannesburg and the Protechnik Laboratories in Pretoria where the analyses were conducted. We 
also would like to express our gratitude to Penelope Theodorou who was the quality manager for the study.

Conflicts of Interest: The authors declare no competing interests.

\section{References}

1. Iavicoli, I.; Carelli, G.; Stanek, E.; Castellino, N.; Calabrese, E. Effects of low doses of dietary lead on red blood cell production in male and female mice. Toxicol. Lett. 2003, 137, 193-199. [CrossRef]

2. Nevin, R. How lead exposure relates to temporal changes in IQ, violent crime, and unwed pregnancy. Environ. Res. 2000, 83, 1-22. [CrossRef]

3. Rastogi, S. Renal effects of environmental and occupational lead exposure. Indian J. Occup. Environ. Med. 2008, 12, 103-106. [CrossRef]

4. Zhang, A.; Hu, H.; Sánchez, B.N.; Ettinger, A.S.; Park, S.K.; Cantonwine, D.; Schnaas, L.; Wright, R.O.; Lamadrid-Figueroa, H.; Tellez-Rojo, M.M. Association between prenatal lead exposure and blood pressure in children. Environ. Health Perspect. 2012, 120, 445-450. [CrossRef]

5. Nation, J.R.; Gleaves, D.H. Low-level lead exposure and intelligence in children. Arch. Clin. Neuropsychol. 2001, 16, 375-388. [CrossRef]

6. CDC. What Do Parents Need to Know to Protect Their Children? Available online: http://www.cdc.gov/nceh/lead/ACCLPP/ blood_lead_levels.htm (accessed on 21 May 2015).

7. Lockitch, G. Perspectives on lead toxicity. Clin. Biochem. 1993, 26, 371-381. [CrossRef]

8. Adebamowo, E.O.; Scott Clark, C.; Roda, S.; Agbede, O.A.; Sridhar, M.K.C.; Adebamowo, C.A. Lead content of dried films of domestic paints currently sold in Nigeria. Sci. Total Environ. 2007, 388, 116-120. [CrossRef]

9. Cuadrado, C.; Kumpulainen, J.; Carbajal, A.; Moreiras, O. Cereals Contribution to the Total Dietary Intake of Heavy Metals in Madrid, Spain. J. Food Compos. Anal. 2000, 13, 495-503. [CrossRef]

10. Edwards, M.; Triantafyllidou, S.; Best, D. Elevated Blood Lead in Young Children Due to Lead-Contaminated Drinking Water: Washington, DC, 2001-2004. Environ. Sci. Technol. 2009, 43, 1618-1623. [CrossRef]

11. Greenway, J.A.; Gerstenberger, S. An evaluation of lead contamination in plastic toys collected from day care centers in the Las Vegas Valley, Nevada, USA. Bull. Environ. Contam. Toxicol. 2010, 85, 363-366. [CrossRef]

12. Isidra, H.S.M.; Rosalba, R.M.; Carlos, G.G.; Hulme, J.M.; Gustavo, O.F. Factors associated with lead exposure in Oaxaca, Mexico. J. Expo. Sci. Environ. Epidemiol. 2003, 13, 341-347. [CrossRef]

13. Brandao, J.; Okonkwo, O.; Sehkula, M.; Raseleka, R. Concentrations of lead in cosmetics commonly used in South Africa. Toxicol. Environ. Chem. 2012, 94, 70-77. [CrossRef]

14. Orisakwe, O.E.; Nduka, J.K. Lead and cadmium levels of commonly administered pediatric syrups in Nigeria: A public health concern? Sci. Total Environ. 2009, 407, 5993-5996. [CrossRef] [PubMed]

15. Rappaport, S.M. Implications of the exposome for exposure science. J. Expo. Sci. Environ. Epidemiol. 2011, 21, 5-9. [CrossRef]

16. FAO/WHO. Joint FAO/WHO Expert Committee on Food Additives Seventy-Third Meeting. Available online: http://www.who. int/foodsafety/publications/chem/summary73.pdf (accessed on 15 October 2018).

17. USEPA Lead and Compounds (Inorganic) (CASRN 7439-92-1). Available online: http://www.epa.gov/iris/subst/0277.htm (accessed on 1 July 2019).

18. Mahaffey, K.R. Predicting Blood Lead Concentrations from Lead in Environmental Media. Environ. Health Perspect. 1998, 106, 1485-1493. [CrossRef]

19. Zaragoza, L.; Hogan, K. The integrated exposure uptake biokinetic model for lead in children: Independent validation and verification. Environ. Health Perspect. 1998, 106, 1551-1556. [CrossRef] [PubMed]

20. LaKind, J.S. Comparison of three models for predicting blood lead levels in children: Episodic exposures to lead. J. Expo. Anal. Environ. Epidemiol. 1998, 8, 399-406.

21. CDTSC. 2007. LeadSpread 7. Available online: http:/ / www.dtsc.ca.gov/AssessingRisk/leadspread7.cfm (accessed on 1 July 2020).

22. USEPA. All-Ages Lead Model (AALM) Version 1.05 (External Draft Report). 2012. Available online: http://cfpub.epa.gov/ncea/ $\mathrm{cfm} /$ recordisplay.cfm?deid=139314 (accessed on 5 February 2020).

23. Oflaherty, E.J. Physiologically based models for bone-seeking elements: IV. Kinetics of lead disposition in humans. Toxicol. Appl. Pharmacol. 1993, 118, 16-29. [CrossRef]

24. Rasmuson, J.O.; Rasmuson, E.; Olsen, R.L.; Hall, D.; Strode, R.; Larson, D.M.; Korchevskiy, A. Application of a Bio-Kinetic Model (IEUBK) to Estimate the Effectiveness of Different Soil Remediation Scenarios for Lead Contamination in Shymkent, Kazakhstan. ХАБАРШЫСЫ 2012, 4, 1-8.

25. Zhong, B.; Giubilato, E.; Critto, A.; Wang, L.; Marcomini, A.; Zhang, J. Probabilistic modeling of aggregate lead exposure in children of urban China using an adapted IEUBK model. Sci. Total Environ. 2017, 584, 259-267. [CrossRef]

26. Lewandowski, T.A.; Forslund, B.L. Comparison of IEUBK model predictions and actual blood lead values at a former battery recycling site. Environ. Geochem. Health 1994, 16, 217-222. [CrossRef] [PubMed]

27. Mickle, M.H. Structure, use, and validation of the IEUBK model. Environ. Health Perspect. 1998, 106, 1531-1534. [CrossRef] 
28. Sathyanarayana, S.; Beaudet, N.; Omri, K.; Karr, C. Predicting children's blood lead levels from exposure to school drinking water in Seattle, Washington, USA. Ambul. Pediatrics 2006, 6, 288-292. [CrossRef]

29. Wang, B.; Shao, D.; Xiang, Z.; Ye, H.; Ni, W.; Yang, S.; Wu, C.E.; Li, P.; Fu, H. Contribution of environmental lead exposure to blood lead level among infants based on IEUBK model. J. Hyg. Res. 2011, 40, 478-480.

30. Laidlaw, M.A.; Mohmmad, S.M.; Gulson, B.L.; Taylor, M.P.; Kristensen, L.J.; Birch, G. Estimates of potential childhood lead exposure from contaminated soil using the US EPA IEUBK Model in Sydney, Australia. Environ. Res. 2017, 156, 781-790. [CrossRef]

31. Cornelis, C.; Berghmans, P.; Sprundel, M.; Auwera, J. The use of the IEUBK model for determination of exposure routes in view of site remediation. Hum. Ecol. Risk Assess. 2006, 12, 963-982. [CrossRef]

32. von Lindern, I.; Spalinger, S.; Petroysan, V.; von Braun, M. Assessing remedial effectiveness through the blood lead:soil/dust lead relationship at the Bunker Hill Superfund Site in the Silver Valley of Idaho. Sci. Total Environ. 2003, 303, 139-170. [CrossRef]

33. Jez, E.; Lestan, D. Prediction of blood lead levels in children before and after remediation of soil samples in the upper Meza Valley, Slovenia. J. Hazard. Mater. 2015, 296, 138-146. [CrossRef]

34. Triantafyllidou, S.; Le, T.; Gallagher, D.; Edwards, M. Reduced risk estimations after remediation of lead (Pb) in drinking water at two US school districts. Sci. Total Environ. 2014, 466, 1011-1021. [CrossRef]

35. Li, Y.; Hu, J.; Wu, W.; Liu, S.; Li, M.; Yao, N.; Chen, J.; Ye, L.; Wang, Q.; Zhou, Y. Application of IEUBK model in lead risk assessment of children aged 61-84months old in central China. Sci. Total Environ. 2016, 541, 673-682. [CrossRef]

36. Chen, F.; Cheng, H.G.; Cui, X.F. Predicting the children's blood lead level in a lead and zinc smelting area based on IEUBK model. Adv. Mater. Res. 2015, 1092, 687-691. [CrossRef]

37. Yang, K.; Cattle, S.R. Bioaccessibility of lead in urban soil of Broken Hill, Australia: A study based on in vitro digestion and the IEUBK model. Sci. Total Environ. 2015, 538, 922-933. [CrossRef] [PubMed]

38. Zheng, J.; Huynh, T.; Gasparon, M.; Ng, J.; Noller, B. Human health risk assessment of lead from mining activities at semi-arid locations in the context of total lead exposure. Environ. Sci. Pollut. Res. 2013, 20, 8404-8416. [CrossRef] [PubMed]

39. NSO. Population and Housing Census; National Statistical Office: Zomba, Malawi, 2008.

40. Mbongwe, B.; Barnes, B.; Tshabang, J.; Zhai, M.; Rajaram, S.; Mpuchane, S.; Mathee, A. Exposure to lead among children aged 1-6 years in the city of Gaberone. J. Environ. Health Res. 2005, 10, 17-26.

41. Naing, L.; Winn, T.; Rusli, B. Practical issues in calculating the sample size for prevalence studies. Arch. Orofac. Sci. 2006, 1, 9-14.

42. WHO. WHO Guidelines on Drawing Blood: Best Practices in Phlebotomy. 2010. Available online: https://www.euro.who.int/__ data/assets/pdf_file/0005/268790/WHO-guidelines-on-drawing-blood-best-practices-in-phlebotomy-Eng.pdf (accessed on 24 April 2018).

43. WHO. Guidelines for Predicting Dietary Intake of Pesticide Residues. 1997. Available online: www.who.int $\backslash \mathrm{T} 1$ $\backslash$ guilsinglrightpublications $\backslash \mathrm{T} 1 \backslash$ guilsinglrightchem $\backslash \mathrm{T} 1 \backslash$ guilsinglrightpesticide_en (accessed on 23 April 2021).

44. Haider, T.; Haider, M.; Wruss, W.; Sommer, R.; Kundi, M. Lead in drinking water of Vienna in comparison to other European countries and accordance with recent guidelines. Int. J. Hyg. Environ. Health 2002, 205, 399-403. [CrossRef]

45. Lewis, R.; Fortmann, R.; Camann, D. Evaluation of methods for monitoring the potential exposure of small children to pesticides in the residential environment. Arch. Environ. Contam. Toxicol. 1994, 26, 37-46. [CrossRef]

46. Sterling, D.A.; Roegner, K.C.; Lewis, R.D.; Luke, D.A.; Wilder, L.C.; Burchette, S.M. Evaluation of Four Sampling Methods for Determining Exposure of Children to Lead-Contaminated Household Dust. Environ. Res. 1999, 81, 130-141. [CrossRef]

47. Farfel, M.R.; Lees, P.S.J.; Rohde, C.A.; Lim, B.S.; Bannon, D.; Chisolm, J.J. Comparison of a Wipe and a Vacuum Collection Method for the Determination of Lead in Residential Dusts. Environ. Res. 1994, 65, 291-301. [CrossRef]

48. USHUD. Guidelines for the Evaluation and Control of Lead-Based Paint Hazards in Housing. Available online: www.hud.gov T1 \guilsinglrightdocuments \T1\guilsinglrightsecond_edition_2012 (accessed on 20 May 2020).

49. NSO. Second Integrated Household Survey, 2004: Household Characteristics, Income and Expenditure Questionnaire; NSO: Zomba, Malawi, 2004.

50. Senekal, M.; Steyn, N.P. The Food Photo Manual; Medical Research Council: Capetown, South Africa, 2004.

51. NSO. Living Standards measurement study: Note on Conversion Factors for Food Item-Non-standard Measurement Unit Combinations. In The Malawi Third Integrated Household Survey (IHS3) 2010/11 Data; NSO: Zomba, Malawi, 2013.

52. USEPA. Exposure Factors Handbook; National Center for Environmental Assessment: Washington, DC, USA, 1997.

53. Hallén, I.P.; Oskarsson, A. Bioavailability of lead from various milk diets studied in a suckling rat model. Biometals 1995, 8, 231-236. [CrossRef]

54. Scorza Júnior, R.; Boesten, J. Simulation of pesticide leaching in a cracking clay soil with the PEARL model. Pest Manag. Sci. 2005, 61, 432-448. [CrossRef]

55. Smith, P.; Smith, J.; Powlson, D.; McGill, W.; Arah, J.; Chertov, O.; Coleman, K.; Franko, U.; Frolking, S.; Jenkinson, D. A comparison of the performance of nine soil organic matter models using datasets from seven long-term experiments. Geoderma 1997, 81, 153-225. [CrossRef]

56. Moriasi, D.N.; Arnold, J.G.; Van Liew, M.W.; Bingner, R.L.; Harmel, R.D.; Veith, T.L. Model evaluation guidelines for systematic quantification of accuracy in watershed simulations. Trans. ASABE 2007, 50, 885-900. [CrossRef]

57. Bland, J.M.; Altman, D.G. Statistical methods for assessing agreement between two methods of clinical measurement. Int. J. Nurs. Stud. 2010, 47, 931-936. [CrossRef] 
58. Fewtrell, L.; Kaufmann, R.; Prüss-Üstün, A. Lead: Assessing the Environmental Burden of Disease at National and Local Levels. Available online: http://www.who.int/quantifying_ehimpacts/publications/en/leadebd2.pdf (accessed on 8 March 2016).

59. Bland, J.M.; Altman, D.G. Applying the right statistics: Analyses of measurement studies. Ultrasound Obstet. Gynecol. 2003, 22, 85-93. [CrossRef]

60. Bradham, K.D.; Dayton, E.A.; Basta, N.T.; Schroder, J.; Payton, M.; Lanno, R.P. Effect of soil properties on lead bioavailability and toxicity to earthworms. Environ. Toxicol. Chem. An Int. J. 2006, 25, 769-775. [CrossRef] [PubMed]

61. Rabinowitz, M.B.; Kopple, J.D.; Wetherill, G.W. Effect of food intake and fasting on gastrointestinal lead absorption in humans. Am. J. Clin. Nutr. 1980, 33, 1784-1788. [CrossRef] [PubMed]

62. Peijnenburg, W.; Jager, T. Monitoring approaches to assess bioaccessibility and bioavailability of metals: Matrix issues. Ecotoxicol. Environ. Saf. 2003, 56, 63-77. [CrossRef]

63. Gersberg, R.M.; Gaynor, K.; Tenczar, D.; Bartzen, M.; Ginsberg, M.; Gresham, L.S.; Molgaard, C. Quantitative modeling of lead exposure from glazed ceramic pottery in childhood lead poisoning cases. Int. J. Environ. Health Res. 1997, 7, 193-202. [CrossRef]

64. Batres-Marquez, S.P.; Jensen, H.H.; Upton, J. Rice Consumption in the United States: Recent Evidence from Food Consumption Surveys. J. Am. Diet. Assoc. 2009, 109, 1719-1727. [CrossRef]

65. Duan, X.; Shen, G.; Yang, H.; Tian, J.; Wei, F.; Gong, J.; Zhang, J.J. Dietary intake polycyclic aromatic hydrocarbons (PAHs) and associated cancer risk in a cohort of Chinese urban adults: Inter-and intra-individual variability. Chemosphere 2016, 144, 2469-2475. [CrossRef] [PubMed]

66. Beerman, K.A.; Dittus, K. Sources of error associated with self-repots of food intake. Nutr. Res. 1993, 13, 765-770. [CrossRef]

67. Lacey, R.F.; Moore, M.R.; Richards, W.N. Lead in water, infant diet and blood: The Glasgow duplicate diet study. Sci. Total Environ. 1985, 41, 235-257. [CrossRef]

68. Stanek, K.; Manton, W.; Angle, C.; Eskridge, K.; Kuehneman, A.; Hanson, C. Lead Consumption of 18- to 36-Month-Old Children as Determined from Duplicate Diet Collections: Nutrient Intakes, Blood Lead Levels, and Effects on Growth. J. Am. Diet. Assoc. 1998, 98, 155-158. [CrossRef]

69. JECFA. Codex Alimentarius: Code of Practice for the Prevention and Reduction of Lead Contamination in Foods. Available online: http:/ / www.fao.org/fao-who-codexalimentarius/codex-texts/codes-of-practice/en/ (accessed on 23 October 2020).

70. Kumar, A.; Mms, C.P.; Chaturvedi, A.K.; Shabnam, A.A.; Subrahmanyam, G.; Mondal, R.; Gup-ta, D.K.; Malyan, S.K.; Kumar, S.; Khan, S.; et al. Lead toxicity: Health haz-ards, influence on food chain, and sustainable remediation approaches. Int. J. Environ. Res. Public Health 2013, 2179, 1-33. [CrossRef]

71. Fralick, M.; Thomspson, A.; Mourad, O. Lead toxicity from glazed ceramic cookware. CMAJ 2016, 188, E521-E524. [CrossRef] [PubMed]

72. Zahran, S.; Laidlaw, M.A.; McElmurry, S.P.; Filippelli, G.M.; Taylor, M. Linking source and effect: Resuspended soil lead, air lead, and children's blood lead levels in Detroit, Michigan. Environ. Sci. Technol. 2013, 47, 2839-2845. [CrossRef] [PubMed]

73. Mathee, A.; von Schirnding, Y.E.R.; Levin, J.; Ismail, A.; Huntley, R.; Cantrell, A. A survey of blood lead levels among young Johannesburg school children. Environ. Res. 2002, 90, 181-184. [CrossRef]

74. Li, T.; Dai, Y.-H.; Xie, X.-H.; Tan, Z.-W.; Zhang, S.-M.; Zhu, Z.-H. Surveillance of childhood blood lead levels in 11 cities of China. World J. Pediatr. 2014, 10, 29-37. [CrossRef]

75. USEPA. Validation strategy for the Integrated Exposure Uptake Biokinetic Model for Lead in Children. Available online: https: / / citeseerx.ist.psu.edu/viewdoc/download?doi=10.1.1.117.5739\&rep=rep1\&type=pdf (accessed on 14 June 2021).

76. Gulson, B.; Taylor, A.; Stifelman, M. Lead exposure in young children over a 5-year period from urban environments using alternative exposure measures with the US EPA IEUBK model-A trial. Environ. Res. 2018, 161, 87-96. [CrossRef]

77. Rudge, C.V.; Röllin, H.B.; Nogueira, C.M.; Thomassen, Y.; Rudge, M.C.; Odland, J.Ø. The placenta as a barrier for toxic and essential elements in paired maternal and cord blood samples of South African delivering women. J. Environ. Monit. 2009, 11, 1322-1330. [CrossRef] [PubMed]

78. Gulson, B.L.; Jameson, C.W.; Mahaffey, K.R.; Mizon, K.J.; Patison, N.; Law, A.J.; Korsch, M.J.; Salter, M.A. Relationships of lead in breast milk to lead in blood, urine, and diet of the infant and mother. Environ. Health Perspect. 1998, 106, 667-674. [CrossRef] [PubMed]

79. Rabinowitz, M.B.; Wetherill, G.W.; Kopple, J.D. Kinetic analysis of lead metabolism in healthy humans. J. Clin. Investig. 1976, 58, 260. [CrossRef] [PubMed]

80. Rabinowitz, M.B. Toxicokinetics of bone lead. Environ. Health Perspect. 1991, 91, 33-37. [CrossRef]

81. Thomas, V.M.; Socolow, R.H.; Fanelli, J.J.; Spiro, T.G. Effects of Reducing Lead in Gasoline: An Analysis of the International Experience. Environ. Sci. Technol. 1999, 33, 3942-3948. [CrossRef] 